\title{
The European Union and the Insiders/Outsiders of Europe: Russia and the Post-Soviet Space
}

\author{
Sabine Fischer ${ }^{1}$ \\ ${ }^{1}$ European Union Institute for Security Studies, Paris, France \\ Correspondence: Sabine Fischer, European Union Institute for Security Studies, 43 Avenue du Président Wilson, \\ 75775 Paris cedex 16, France. Tel: 33-1-56-891-968. E-mail: sabine.fischer@iss.europa.eu
}

Received: November 24, 2011 Accepted: April 26, 2012 Online Published: July 1, 2012

doi:10.5539/res.v4n3p32

URL: http://dx.doi.org/10.5539/res.v4n3p32

\begin{abstract}
The European Union is being perceived in Eastern Europe as an important actor, but with very different connotations. Some neighbours have membership ambitions and see the EU as a model (cf. the enlargement/democracy narrative). For others, relations with the EU are an instrument to balance regional relations (cf. the geopolitical narrative). Finally, some perceive the EU as striving to expand its influence beyond its borders (cf. the value empire narrative). The chapter investigates the discourses on the EU in the eastern neighbourhood and Russia. It starts from the assumption that perceptions in the region have a strong impact on the EU's ability to pursue its policy goals. At the same time, EU policy influences debates in its partner countries. By examining this interrelationship this paper aims to understand the extent to which the EU is able to play the role of an important regional actor in the post-Soviet space.
\end{abstract}

Keywords: Russia, European Union, acquis communautaire, European neighbourhood policy, identities, constructivism, foreign policy, enlargement fatigue, geopolitical narrative

\section{Introduction}

In its 2003 Security Strategy the EU ascribed to itself the task 'to promote a ring of well-governed countries to the East of the European Union [and on the borders of the Mediterranean] with whom we can enjoy close and cooperative relations' (EU Council 2003, p. 8). The publication of the European Security Strategy (ESS) was a landmark moment in the development of EU foreign and security policy. For the first time ever Member States had agreed on a common document on the EU's role and policy in a changing international environment. As the quotation above demonstrates, the ESS defines the EU as a normative power in relations with its neighbourhood by explicitly spelling out the aim to shape polities in neighbouring states and assist them on the road to good governance.

Since its 'big bang' enlargement in 2004 the EU has clearly evolved into a key actor in its Eastern neighbourhood (Note 1). It is the biggest provider of humanitarian aid and technical assistance and the most important trade partner for many of the countries in the region. Brussels and the countries in Eastern Europe and the South Caucasus (including Russia but with the exception of Belarus) have developed a dense network of political and legal relations, which partly implies the adoption of the acquis communautaire by the EU's partners in the East.

However, the EU's relations with the countries in the region do not evolve in a linear continuum. On the contrary, they are marked by significant ups and downs. The eastern enlargement in 2004, the development of the European Neighbourhood Policy (ENP) and the colour revolutions all contributed to a rapid rapprochement with the countries of the Eastern Neighbourhood. This rapprochement, however, was accompanied by a rapid deterioration in relations with Russia. Today it is impossible to argue that any country in the region is better governed than seven years ago - some countries have even become considerably more authoritarian and corruption remains an insurmountable obstacle to more sustainable development. Tensions in the region persist and the conflicts in Moldova, Georgia and Azerbaijan remain unresolved. An elite poll conducted in summer 2010 by the Centre for European Policy Studies (2010) revealed that almost two thirds of the respondents (from both the EU and partner countries) assessed the ENP as having 'little or no impact'. 
This leaves the observer with the puzzling question of what happened to the EU's ambitious claim to create a ring of well-governed states along its new borders. This essay intends to respond to this question in three steps. First, it will give a brief overview of the EU's policies and policy instruments in the region. Secondly, it will look into the perceptions and views of the EU and its policies in the region. The insights offered in this section do not rely on a systematic discourse analysis but on numerous interviews and conversations with experts, policy makers and civil society representatives in Russia and the countries of the Eastern Neighbourhood of the Union. The conclusion will provide an answer to the question alluded to above based on the assumption that the EU and its Eastern neighbours find themselves in a complex relationship in which different perceptions and attitudes held by the neighbours limit the EU's space for manoeuvre (Note 1) to pursue its goals while on the other hand the EU's actions (or reluctance to act) influences debates and attitudes in the partner countries.

\section{Conceptual Considerations}

As outlined above, this article starts from the assumption that different narratives relating to the EU have an important role to play in the Union's relations with its eastern neighbours. The perspective used for this analysis is therefore anchored in the constructivist approach in International Relations theory. Constructivism and its emphasis on the role of ideational factors for the foreign policy of states and international relations in more general terms (re)entered the debate on international relations with the end of the Cold War in the late 1980s. With the bipolar structure of the international system crumbling, both political actors and analysts struggled to come up with explanations of the changes afoot and their policy implications as well as political programmes for how to react to those changes (Hudson, 1997; Lapid/Kratochwil, 1996; Weldes, 1996). Scholarly attention focused increasingly on discourses in which societies interpreted revolutionary change in international relations and tagged it with meaning (Milliken, 1999). Constructivism in its different forms has managed to firmly establish itself as a conceptual approach in IR since then. In the post-Soviet space, a region which is still in flux, it remains an attractive analytical model to explain change in regional relations.

Narratives are stories, here told about the EU's nature, intentions and policies towards its neighbours. They form part of the discourses in the respective societies and among political elites, which build the ideational background of political decision-making in the EU's eastern partner countries. They resemble pieces of an ideational puzzle and are closely linked to ideas of the identity of a state, its appropriate foreign policy and external relations, its place in the world (Fischer, 2003, pp. 56). Together these ideational components form world views which may or may not become the basis of a state's foreign policy behaviour (Goldstein/Keohane, 1993).

Discourses on identity, foreign policy, and relations with the EU are characterised by a plurality of positions in all neighbouring countries. This article, however, does not look into the respective national discourses but takes into consideration only the narratives which determine state policies at a given point in time.

Neither does it give an in-depth analysis of the ideational and normative background of the EU's policy itself. However, a number of assumptions about EU policy need to be spelled out here. First of all, the EU is a hybrid foreign policy actor. There is not one single actor, i.e. a government, which defines and exerts foreign policy, but a variety of actors who influence and enact the Union's foreign policy at different levels: Member States, the Commission, the European Parliament, the emerging European External Action Service. The most striking differences often appear between the European Commission as a 'normative actor' and the more realpolitik approaches of Member States. Second, because the EU is a hybrid foreign policy actor and to date lacks a cohesive unifying force which could rein in and discipline the different players, it tends to send varying and often contradictory signals to its outside partners both in terms of its interests and values.

This article deals with eastern European narratives about relations with the EU. They are anchored in historically rooted ideas of identity and relations with the outside world and give orientation and meaning to the respective countries' foreign policy and attitude towards the EU. As will become clear in the analysis these narratives are very different and fulfil different internal and external functions. Hence, EU norms and values encounter very different receptions in different countries. If they are compatible with the dominant ideas in the national discourse, they will be embraced. If they are not compatible, they will be either partially embraced or rejected. In some cases ruling elites may be tempted to shield societies from EU values of democracy and human rights in order not to undermine their leadership.

The EU claims to support democratic and market transformation in its eastern (and southern) neighbourhood. Policies such as the European Neighbourhood Policy and the Eastern Partnership can therefore be analytically conceptualised as instruments of socialisation. Ultimately, they aim at instigating fundamental change of the identities of neighbouring polities and societies, at making these countries and societies 'more like us'. Socialisation requires learning on the part of the eastern neighbours. Learning can be 'simple' when learning actors 
merely adjust their behaviour to expectations of their environment. Complex learning, on the other hand, implies changes in actors' identity and interests (Wendt, 1999, 170; Gross-Stein, 1996). In other words, while the EU expects complex learning from its neighbours, whether the neighbours are prepared to undertake this kind of learning very much depends on the political conditions and discourses in the respective countries - and on the incentives the EU is prepared and able to offer them. The modest success of the ENP and the EaP in promoting democracy and market reform in the eastern neighbourhood suggests that to date the EU has not been able to seduce its neighbours into complex learning.

\section{EU Policy towards the Eastern Neighbours and Russia}

Throughout the 1990s the EU concluded Partnership and Cooperation Agreements (PCAs) with all post-Soviet states (Note 2). PCAs are mixed agreements focused on the regulation of economic cooperation, trade and EU technical assistance to economic and, to a lesser extent, political reform. The PCAs with the post-Soviet states are fairly similar in structure and content. Initially concluded for a duration of 10 years, all PCAs are still in force. However, the EU's relations with Russia, Belarus, Ukraine, Moldova, Georgia, Armenia and Azerbaijan have taken very different trajectories in the past 10 years. This is increasingly reflected in the differentiation of political frameworks for those relations.

In the years 2002-2004 the EU, in parallel to the preparation of the 2004 round of enlargement, developed the ENP to shape relations with its new neighbours to the East and to the South. The ENP offers a number of additional incentives compared to previous policies by elevating their political and symbolic status and increased funding in the framework of the European Neighbourhood and Partnership Instrument (ENPI) (Marchetti, 2008, p.29). Moreover, the ENP opens the perspective of deeper integration with the European Single Market. At the same time, however, it explicitly denies a membership perspective. Bearing in mind the need to create a stable and secure neighbourhood, this policy tried to tread a tightrope between 'enlargement fatigue' within the Union on the one hand and finding a way of responding to the increased ambitions among the eastern neighbours on the other hand. At the core of the ENP are the so-called ENP Action Plans which outline concrete reform measures in relevant areas for the ENP countries to implement in order to achieve the above- mentioned goals. Ukraine was the first eastern neighbour to conclude an ENP Action Plan in 2005. It was followed by Moldova in 2005 and the three South Caucasian countries in 2006. Ukraine was also the first ENP country to start negotiations with the EU on a new agreement which should more fully reflect the deepened relationship. At the time the 'Orange' administration in Kyiv had strong European ambitions and demanded this be reflected in the new legal document. Both sides ultimately agreed to negotiate an association agreement, which would later become a model for the other eastern ENP countries.

Russia refused to participate in the emerging ENP and insisted on a special role and position in the EU's relations with the countries in the post-Soviet space (Delcour, 2011). As a consequence, the EU and Russia set out to develop a different framework for their relations, and adopted Road Maps to the so-called Four Common Spaces in 2005 (Note 3). In anticipation of the expiry of the PCA in 2007 the sides started to prepare to negotiate a new agreement in 2006. However, the rapid deterioration of political relations between the EU and Russia in the same period and a Polish veto on the start of the negotiations in 2007 slowed down the process. Brussels and Moscow have been negotiating since spring 2008, with a three-month interruption in reaction to the Russian-Georgian war in August 2008. Negotiations are difficult and protracted particularly in the area of trade and energy relations, and it remains difficult to predict when a new agreement will be concluded. Fundamental differences persist. Most tellingly, the sides have problems in reaching consensus on the title of the agreement. While the Russian side prefers a framework agreement which could then be substantiated with sectoral agreements in the four Common Spaces, the EU insists on a comprehensive agreement which covers all areas of EU-Russia political and economic cooperation.

In 2008, Poland and Sweden put forward a proposal regarding the deepening of the Eastern dimension of the ENP. This 'Eastern Partnership' (EaP) was designed to differentiate EU policy in the framework of the ENP, to provide the Eastern ENP countries with clearer incentives for good performance under the ENP Action Plans, and by doing so to speed up their rapprochement with the Union (Pelzynska-Nalecz, 2011). The EaP was boosted by the 2008 war in Georgia (Presidency Conclusions 2008). The main pillars of the Eastern Partnership (EaP) are Association Agreements as well as accelerated negotiations on deep and comprehensive Free Trade Agreements and on visa facilitation.

The Eastern Partnership also adds a multilateral dimension to the otherwise bilateral ENP. This multilateral track of the EaP contains thematic platforms and flagship initiatives for cross-border sectoral cooperation, a regional 
Civil Society Forum, and a parliamentary assembly (Euronest). This framework aims to give the EU an 'additional instrument' to accompany regional cooperation processes in the eastern neighbourhood (COM 2008-823, p.8).

The EU has also become more visible as a security actor in its eastern neighbourhood (Popescu, 2011). It has become directly involved in the peace negotiations on the Moldova-Transnistria conflict as an observer in 2005, and has been co-chairing the Geneva Talks on the conflicts over Abkhazia and South Ossetia since the Russian-Georgian war in August 2008. It deployed a border assistance mission (EUBAM) along the Transnistrian stretch of the Moldovan-Ukrainian border in 2005 and a civilian monitoring mission in Georgia in 2008 (Dura 2009, Fischer 2009, Huff 2011). Several EUSRs have dealt with the unresolved conflicts since 2003. The conflicts are also addressed in the framework of the European Neighbourhood Policy and the Eastern Partnership. Assistance to economic development, state building and democratisation of the affected states are considered effective tools to make those countries more attractive in the eyes of the breakaway regions and spark their interest in reintegration. Rapprochement with the EU is seen as a way to dissolve tensions, curb nationalist trends and transform conflicts in the region (Noutcheva et al., 2004; Triantaphyllou/Tsantoulis, 2008).

The EU has not been overly successful in influencing the consolidation of democracy, good governance and the rule of law in its eastern neighbourhood. On the contrary, compared to the situation in 2003/2004 the region has become more authoritarian (Fischer, 2011). Brussels and Moscow have been at odds over the EU's democracy agenda for most of the past decade already. Georgia after the Rose Revolution in 2003 has achieved considerable macroeconomic results through economic reform and liberalisation, but has not made similarly fast progress in democratisation. Ukraine's ambitions for democratisation have diminished since the change of power from Yushchenko to Yanukovich early in 2010. The Azeri leadership is consolidating a political system with strong democratic flaws, and Belarus slid back into authoritarianism after the presidential elections in December 2010. At the time of writing, only Moldova is frequently being cited as a successful example of the EU's efforts to promote its values in its eastern neighbourhood.

\section{The Eastern Neighbours and Russia: Views of the $\mathbf{E U}$}

Throughout history 'Europe' has been an important reference for Eastern European societies' identity, whereby 'European' usually signifies an advanced stage of cultural and economic development (Neumann, 1996 and 1999). This connotation of 'Europe' penetrates elite discourses as well as everyday language. In Russian-speaking regions, for instance, the term 'evroremont' ('Euro-renovation') provides an illuminating example. It denotes high-quality refurbishment of flats and houses in a style which is supposedly redolent of Western European influences. The term has become quite widespread over the past 15 years and is used in colloquial and official language as well as in advertising.

Following the downfall of the Soviet Union an ever closer link emerged in Eastern European discourses between 'Europe' and the European Union, implying a rift between truly European insiders (EU Member States and societies) and somewhat less European outsiders. This is paradoxical given the fact that Russia, Belarus, Ukraine and Moldova are geographically European. In the South Caucasus Armenia and Georgia consider themselves to be ancient European cultures and point to their long Christian tradition. Nevertheless there is a clear rift in Eastern European discourses between an EU-Europe of insiders and the Eastern European outsiders (White et. al., 2008; White et. al., 2010).

From the perspective of the Russian elite and society, the downfall of the USSR and the transition to democracy became traumatically associated with the dismantling of the empire and subsequent deep political and economic crisis. Along with this came a painful loss of influence on and symbolic connection with the neighbouring countries which from a Russian perspective was particularly severe in the cases of Belarus and Ukraine. Moreover, in the Russian collective memory the socio-economic transformation of the 1990s became negatively associated with Western values and Western influence on developments in Russia and the post-Soviet space.

For the so-called 'Newly Independent States' (NIS) the end of the Soviet Union signified exactly the opposite. Here, transition became linked to obtaining independence and sovereignty for the first time since the short period of independence from Tsarist rule between 1917 and 1922. Tellingly, the notion of 'Newly Independent States' (novye nezavismye gosudarstva) is used for all post-Soviet states apart from the Russian Federation despite the fact that Russia in its 1992 borders was as newly independent as its neighbours. Regardless of the transformation trajectories Russia's neighbours took after 1992 - ranging from genuine efforts to reform (Ukraine, Moldova, Georgia) to the establishment of authoritarian regimes (Belarus, Azerbaijan) - independence and the protection of their sovereignty remained an important issue for their political elites and societies.

As will be shown in this section, these antagonistic interpretations of the recent past strongly influenced the perceptions of the EU in the post-Soviet space as it became more visible as an actor in the region. 
Moreover, diverging perceptions of the EU are to be found at the domestic level in the post-Soviet states. In every country and society, competing political forces promote different concepts of national identity, desirable political order and relations with the outside world. Perceptions of the EU and ideas about how best to interact with it are part of these concepts. Conversely, domestic constellations of power and ideas about the EU constitute the background against which EU policy operates and thus have significant bearing on its space for manoeuvre.

A broader look at the discourses in the post-Soviet space brings to the fore three ideal-type narratives on the EU: the democracy/integration narrative, the geopolitical narrative and the 'value empire' narrative. This section will depict these competing narratives in more detail and also discuss where and when they could be observed in the post-Soviet space.

\subsection{The Democracy/Integration Narrative}

In the democracy/integration narrative the EU appears as a model for development. Its members have accomplished democracy. Their economies prosper and their societies are free. EU Member States have managed to govern their relations without using military force and have turned Western Europe into a zone of peace, stability and free interaction between societies and a benign international actor. The understanding of the EU in the democracy/integration narrative has far-reaching implications for the domestic and foreign policies of outsiders. At the domestic level the outsiders' main aim must be to build up a democratic political system and a market economy, to strengthen the rule of law and to create an environment which favours the emergence of an open and free society. Only internal reform geared towards the consolidation of democracy creates the conditions which will allow outsiders to integrate with the EU. Inclusion is the main aim and endpoint of the outsiders' historical trajectory.

Accordingly, proponents of the democracy/integration narrative want the foreign policy of their countries to focus on relations with the consolidated democracies of the West. Neighbours in the post-Soviet space who share their ambition are welcome to join forces to reach the common goal. However, the purpose of these alliances is not regional integration per se, but inclusion into existing European structures (Note 4). For instance, President Yushchenko declared in his inaugural speech in January 2005: 'Our way to the future - is the way followed by the United Europe. We are the people of the same civilisation sharing the same values. History, economic prospects and the interest of people give a clear answer - where we should look for our fate. Our place is in the European Union. My goal is - Ukraine in the United Europe'. In a very similar vein Georgian President Saakashvili explained in his second inaugural speech in January 2008: 'Georgia is forever yoked to Europe. We are joined by a common and unbreakable bond - one based on culture, on our shared history and identity - and on a common set of values that has at its heart the celebration of peace, and the establishment of fair and prosperous societies'.

The wish to democratise, catch up with the Western community of democratic states and, ultimately, to become a part of it, blurs the boundary between the outside and the inside. The EU's claim to extend its spaces of governance and to shape and transform the domestic order of its neighbours by promoting its acquis communautaire (Gänzle, 2009) is not perceived as a threat to sovereignty and independence, but as a logical step towards the desired goal of europeanisation. This goal is achieved once the outsider crosses the boundary and becomes an EU member.

In Ukraine and Georgia, the democracy/integration narrative has had a very strong influence on public debates and government policy in recent years. After the 2003 Rose Revolution in Georgia and the 2004 Orange Revolution in Ukraine both new administrations embarked on a policy of political and economic reforms and rapid integration with Western international organisations. The Orange leadership under President Yushchenko put a stronger emphasis on rapprochement with and, ultimately, accession to the EU. Georgia under President Saakashvili quickly developed a strong transatlantic bond and placed more hope on American support for NATO accession. Nevertheless both governments actively lobbied for quick rapprochement with the EU and a stronger EU role in the post-Soviet space. For instance, one of the first foreign policy initiatives of the Yushchenko administration was a plan for the resolution of the Transnistria conflict in which the EU played a major role. Consequently the deployment of the EUBAM along the Transnistrian stretch on the Ukrainian-Moldovan border was a response to Ukrainian (and Moldovan) calls for more EU engagement (Fischer 2008, Dura 2010). The Georgian government too strove for an internationalisation of conflict resolution in Abkhazia and South Ossetia and for an increased EU role long before the Russian-Georgian war in August 2008 (Fischer 2010, Popescu 2011). For both Kyiv and Tbilisi, rapprochement with the EU (and NATO) had a strong security dimension and was closely related to their position vis-à-vis Russia. The desire to 'become European', democratise and integrate with Western European international organisations was inextricably linked with an overwhelming perception of a threat to sovereignty, territorial integrity and independence emanating from Russia. 
In Russian discourses the democracy/integration narrative was most visible and influential in the political debates and decision-making processes during the 1990s (Fischer, 2003). Gorbachev's idea of a Common European Home was followed by the strong pro-Western rhetoric of Russian Foreign Minister Andrey Kozyrev in the early Yeltsin era. Russia's potential EU (and NATO) accession was discussed on a regular basis - even though it was never made an official foreign policy position. Pro-Western, liberal forces propagated Russia's 'return to Europe' and 'integration into Europe' after decades of authoritarian Soviet rule.

Proponents of this view, however, became increasingly marginalised towards the end of the first decade of Russian post-Soviet independence. Andrey Kozyrev and his supporters lost their political clout in the middle of the 1990s. After the Kosovo war in 1999 the image and perception of Western state actors and international organisations in Russian society changed for the worse. This development further undermined the domestic position of those political forces associated with Western ideas. European integration was increasingly ruled out as a political option for Russia (Note 5). The marginalisation of liberal parties and organisations was reinforced by growing authoritarian tendencies during the Putin era. In today's Russia only a very small part of the political elite subscribes to views which come close to the democracy/integration narrative.

Moreover, representatives of the liberal political spectrum themselves became more critical of the EU due to its attempts to cooperate pragmatically with the Russian leadership. For Russian liberals this interest-based approach was a betrayal of the values that the EU claims to promote in its foreign policy. This view is also shared by opposition forces in other post-Soviet countries criticising the EU for being too government-oriented and for engaging too little with civil society (Bosse, 2009). The EU's unwillingness or inability to effectively put pressure on Moscow to observe democratic and human rights standards undermined their own efforts to promote such standards in Russia. Moreover, pro-European Russians increasingly resented what they perceived as a hierarchical and exclusive approach of the EU towards Russia. One important example is the EU's reluctance to concede visa-free travel to Russian citizens (Prozorov, 2007). This attitude also concerns Russia's relations with its post-Soviet neighbours. However critical they may be of the policy of the Russian leadership, many liberal political actors share the view that Russia should play a special role in the region (Chubais, 2003).

\subsection{The Geopolitical Narrative}

In the geopolitical narrative the EU is considered one of several external actors engaged in the post-Soviet space. Regional relations are characterised by competition because 20 years after the breakdown of the Soviet Union a new balance of power has yet to emerge. The number of regional and external powers involved has steadily increased over these past two decades. Next to Russia, the US, NATO and the EU powers such as Turkey, Iran and China play a more important role in the Black Sea region, the South Caucasus and Central Asia. Each of these actors is guided by a specific set of strategic interests and preferences and has different strategies and instruments at their disposal. Regional relations unfold according to the rules of realpolitik. Political and military power projection is the most efficient means to realise one's interests. In such a balance-of-power system sovereignty and non-interference play a crucial role in state-to-state relations.

Compared to Russia, the US or NATO, the EU is perceived as a rather weak player in the geopolitical narrative. Russia, the US or NATO are considered much more capable of shaping the geopolitical balance in the region. At the same time, however, the EU's relative political and in particular economic weight in the region has steadily increased in the past 10 years. Not only has it become a direct neighbour of many states in the region after the 2004 enlargement - it is also their most important source of technical assistance and biggest trading partner. Hence, it can no longer be neglected as a protagonist in the processes of balancing and counterbalancing in the region.

Like its democracy/integration counterpart, the geopolitical narrative exists everywhere in the post-Soviet space. In an environment where foreign policy thinking is determined by a traditional understanding of international relations as a balance of power game among nation states it is particularly strong. Clearly there is a rift between the geopolitical narrative and the post-modern self-description of the European Union.

The geopolitical narrative is a driving force behind the policies of those governments in the post-Soviet space who strive to counterbalance the influence of several external actors.

Perhaps the most striking example of this approach is Belarus between 2008 and 2010 where authoritarian President Lukashenka tried to move away from total dependence on Russia by cautiously opening up towards the EU (Gromadzki, 2009). Already before the presidential elections on 19 December 2010, however, it had become clear that for the Belarusian leadership rapprochement with the EU was first of all a tactical move. Moreover, given Belarus' almost complete economic dependence on Moscow Minsk could not realistically expect the EU to substitute for Russian economic subsidies. However, Lukashenka saw a possibility to put pressure on Moscow by seeking closer relations with the EU and signalling that Russia might lose its most faithful partner country in its 
Western neighbourhood. Obviously, this move was not based on a serious interest in sustainable reform of the Belarusian leadership. Nevertheless the reluctant domestic changes made between 2008 and 2010 opened channels for the opposition and civil society to step up their activities. This forced the regime to revert to repressive measures when things seemed to get out of control. The brutal crackdown on demonstrations against the regime on 19 December indicates that for the time being the Belarusian leadership under Lukashenka has returned to a repressive approach. However, given the negative reaction to these events in both Moscow and Brussels it is much less likely that it will be able to pursue its geopolitical balancing act between the EU and Russia in the future.

The geopolitical paradigm also informed the so-called 'multi-vector policy' of former Ukrainian President Leonid Kuchma (1996-2004). In order to counterbalance Russian influence on domestic politics and, particularly, the Ukrainian economy, Kuchma pursued a policy of limited rapprochement with the EU and NATO. It was during his presidency that the debate on a Membership Action Plan for Ukraine's NATO accession and EU integration was initiated. At the same time, however, Kuchma's commitment never went as far as allowing for serious political and economic reforms for fear of undermining his party's power base. Hence, 'despite defining their country as European, the elites remained impervious to Europeanisation. [...] European integration was regarded as an exclusively foreign policy matter and remained essentially insignificant in terms of domestic policy making.' (Wolczuk, 2008, p.92) Increasing authoritarian tendencies in Kuchma's rule led relations with the EU (and NATO) to deteriorate towards the end of his second term. During the same period Russian influence grew stronger, reaching a peak in the run-up to the presidential elections in autumn 2004. After the 2010 presidential elections Ukraine seems to have returned to the balancing approach of the Kuchma era. While President Yanukovich (2011) emphasises that 'European integration is our number one priority', he also underlines that 'the specifics of the international situation, where Ukraine found itself after the onset of the global financial crisis, urges us to implement [an] ideologically neutral non-aligned policy. [...] In 2011 Ukraine will continue to develop pragmatic partnerships with Russia, the USA, the EU, China, Turkey [...].' Ukrainian Foreign Minister Gryshenko (2010) describes his country's situation as follows: 'We were torn between two Europes. To the West was the Europe of the EU, one of the most attractive political and economic magnets in human history. To the East was the Russian Federation, with millions of our friends, relatives and a widespread network of connections that nourished the economy. In a way, the choice between East and West was a choice we couldn't really make, because we needed both.'

For the past decade Azerbaijan has been pursuing a policy of careful balancing between various international actors. The country is embedded in a highly complex regional environment. Rich in energy resources, it is at the same time weakened by its dependence on Russia's transit infrastructure. 15 per cent of Azerbaijan's territory is occupied by Armenian troops since the war over Nagorno-Karabakh in the early 1990s. Over the years the political system has consolidated authoritarian features in support of a rent-seeking elite who show little appetite for political or economic reform (ICG, 2010 and 2011). At the same time, Azerbaijan benefits from its strategic position as both an energy exporter as well as a potential hub for energy trade between Central Asia and Western Europe, the US and Turkey. This draws a lot of international attention to this small country on the shore of the Caspian Sea. Clearly, from an Azerbaijani perspective the EU is a weak player. It has much less to offer than, for instance, the US, to bolster Baku's position in the unresolved conflict with Nagorno-Karabakh and Armenia. Moreover, the Azerbaijani leadership is deeply suspicious of the transformative ambition of EU foreign policy which is perceived as in conflict with Azerbaijan's sovereignty. Although Baku has joined the European Neighbourhood Policy and the Eastern Partnership and demonstrates a moderate interest in political and economic cooperation with the EU, cooperation in the areas of human rights and the rule of law unfolds slowly. EU attempts to strengthen the Azerbaijani opposition and civil society through instruments such as the EIDHR are eyed with scepticism from Baku (Alieva, 2011).

Essentially, the geopolitical narrative is particularly strong in countries 'in between' the European Union/NATO and Russia. Usually these countries are characterised by authoritarian tendencies, state weakness and strong dependency on external political and economic support. The ruling elites use foreign policy as a means to preserve power. This goal runs counter to the EU's ambition to promote democracy and the rule of law beyond its borders. Consequently, the EU has many more difficulties in cooperating with those leaderships on a reform agenda. Countries like Azerbaijan with an interest in a strong security dimension of external relations consider the EU a weak counterpart compared to other external players.

Geopolitical thinking could also be traced in Saakashvili's Georgia and Yushchenko's Ukraine in so far as one of the main goals of their reorientation towards the EU and NATO was to find allies in their efforts to fend off Russian assaults against their sovereignty. The main difference between the democracy/integration and the geopolitical narrative consists in the latter's negligence of the EU's transformative aspirations. 


\subsection{The 'Value Empire' Narrative}

The 'value empire' narrative is a close relative of the geopolitical paradigm in that it depicts international relations as an anarchic system in which interest-driven state actors strive for security either through supremacy or balance of power. If broken down to the regional level of the post-Soviet space this understanding implies that, as in the geopolitical narrative, several powers compete for influence in a region in which a balance of power has yet to emerge.

Unlike the geopolitical narrative, however, the 'value empire' narrative puts a special emphasis on the specific nature of the EU as a value-oriented foreign policy actor. However, in this paradigm EU values are not perceived as a positive factor, as they are in the democracy/integration narrative. Rather, proponents of the 'value empire' narrative suspect the EU of using values to gloss over its geostrategic and geo-economic interests and its desire to expand its influence into the post-Soviet space. Hence, the EU's efforts to promote democracy, the rule of law, human rights and the market economy in neighbouring countries does not appear as an attempt to foster their development but rather as an attempt to make its neighbours more dependent and, thereby, realise its own interests. EU policy becomes, from a Russian perspective, a zero sum game: 'We are accused of trying to have spheres of influence. What is the Eastern Partnership? Is it a sphere of influence, we would like to understand? And if [...] Carol Schwartzenberg publicly says that if Belarus recognises [Abkhazia and South Ossetia] it could forget about the Eastern Partnership - is it threatening, is it blackmail, or is it democracy at work? (Lavrov, 2009).' The transformative approach of the EU's foreign policy is seen as a deliberate violation of state sovereignty (Bordachev 2003, Haukkala 2009). The ultimate aim of this policy is to topple existing governments and replace them with leaderships obedient to the EU's will. Moreover, EU values are depicted in this paradigm as culturally specific and alien to the traditions of countries outside the EU (Kratochwil, 2008).

The 'value empire' narrative has dominated much of the Russian debate on the EU during the 2000s (Averre, 2009). It emerged as a reaction to the Union's growing influence in the Western and Southern part of the post-Soviet space before and after the 2004 enlargement. From a Russian perspective, the colour revolutions in Georgia and Ukraine were key events which revealed the EU's real intentions. The Russian political elite and population perceived the downfall of the Russia-friendly leadership in Ukraine and the radical pro-Western shift of both Kyiv and Tbilisi after the revolutions as the result of a Western conspiracy which aimed to push back Russian influence in its immediate neighbourhood and, ultimately, gain control of the region including Russia.

The impact of the 'value empire' narrative has become more moderate since the early 2000s for two reasons. First, Russian fears of a domino effect triggered by the revolutions in Georgia and Ukraine turned out to be exaggerated. Although tensions with Georgia deteriorated and even escalated in a war in August 2008, Russia was able to maintain and even expand its influence in the South Caucasus. After five years of internal turmoil the 2010 presidential elections in Ukraine resulted in a domestic constellation which is very convenient for Moscow. From a Russian perspective, the EU, at least for the time being, has proven unable to transform the cataclysmic events of 2003 and 2004 into a linear trend. Secondly, the 2008 economic crisis forced the Russian leadership to reorganise its domestic and foreign policy priorities. The new accent on the modernisation of the Russian economy, the flagship of Dmitri Medvedev's presidency, required a readjustment of Russia's attitude towards the EU which is meant to be the main external partner for modernisation. This has led to a change in rhetoric and action on the Russian side, and has opened a new period of rapprochement in EU-Russia relations. However, negative perceptions remain deeply entrenched in Russian political discourses and public opinion.

Belarus before 2008 provides another example of the 'value empire' narrative. Based on Russian economic support, the Belarusian leadership created an image of the EU and other Western actors as hostile forces who threatened Belarus' independence and sovereignty. State control of mass media and the relative isolation of Belarusian society along with the daunting example of post-revolutionary Ukraine helped Lukashenka to create the atmosphere of a besieged fortress threatened by the EU's attempts to infringe on the country's sovereignty. Seen from this perspective the EU sanction policy may even have helped the Belarusian leadership to survive the changes which swept the region during that period (Leshchenko 2008, Fischer 2009).

\section{By Way of Conclusion: The EU's Role and Impact in the Post-Soviet Space}

This essay has focused on perceptions of the EU in the countries of the Eastern Neighourhood and Russia. The various paradigms described in the previous section have been present in the national discourses on foreign policy and identity in different forms in all countries at all times since the breakdown of the Soviet Union. Their strength in domestic debates and impact on foreign policy making has been dependent on both internal and external factors.

The democracy/integration narrative gained strength in both Ukraine and Georgia as a countermovement against corrupt and increasingly authoritarian regimes. After the Rose and the Orange revolutions, however, domestic 
factors hampering democratic consolidation persisted. In Georgia, the conflicts with Abkhazia and South Ossetia and the quickly deteriorating relationship with Russia constituted a serious challenge to democratisation. Along with the highly personalised and non-transparent leadership style of President Saakashvili, the tense internal and external situation of the country triggered nationalist policies and undermined the emergence of a pluralist political society (De Waal, 2010). Nevertheless, the Saakashvili administration managed to pursue economic reforms and achieved some improvement in the living standards of the Georgian population. In Ukraine the Orange coalition under the leadership of Viktor Yushchenko and Yulia Timoshenko became bogged down in an internal power struggle right after the revolution and showed little interest in genuine reform projects (Wolowski, 2008). Opaque links with business interests further damaged their reputation. Ukrainians hardly perceived an improvement in their situation after the Orange Revolution. On the contrary, when the global economic crisis hit Ukraine in late 2008 and early 2009, the political leadership proved incapable of protecting its population from its implications. Moreover, the Orange forces had to face a political alternative with strong support in the East of the country. The end of the Orange era in January 2010 also brought a temporary end to the dominance of the democracy/integration paradigm in Ukrainian foreign policy.

Besides these domestic developments there were important external factors which influenced the developments in both Georgia and Ukraine. Clearly, Russia's negative attitude constituted a permanent threat to the two post-revolutionary leaderships. Driven by its fear of a domino effect which could ultimately reach Russia itself, Moscow used economic, energy, political and military leverage (including deliberate provocation of the war in August 2008) in order to destabilise and damage the sovereignty of post-revolutionary Ukraine and Georgia (Popescu/Wilson, 2009).

The EU's policy, too, was of considerable significance, particularly for domestic developments in Ukraine. First of all, the EU was not able to grant Ukraine a membership perspective, which deprived the Orange leadership of the strongest possible argument in favour of domestic reform and integration with Europe. Secondly, especially in the first years after the revolution, the Ukrainian political elite and society received conflicting signals from Brussels and Member States' capitals. Hopes for a membership perspective were triggered by some EU actors and Member States and dashed by others. Thirdly, cooperation between Ukraine and the EU in the framework of the ENP and the Eastern Partnership never met expectations on the Ukrainian side and brought few tangible results for the Ukrainian population. This was partly due to the inability and/or unwillingness of the Orange leadership to pursue a coherent reform policy. In other areas, such as visa facilitation and visa freedom, however, the main obstacles lie with the EU. This is particularly damaging since free movement is the single most important short-term goal in the eyes of the Ukrainian population. By denying Ukraine (and other countries in the region) visa freedom the EU contradicts its own image as an open and inclusive actor and undermines its soft power.

Hence, EU policy towards post-revolutionary Ukraine, despite its achievements, has had a two-pronged negative impact. First, by denying important rewards (membership perspective, visa freedom) the EU did not give the Ukrainian leadership sufficient incentives to embark on genuine reforms. Visa freedom and other concessions by the EU could also have been presented as important foreign policy success to the Ukrainian domestic audience. The lack of such successes undermined the standing of reform-oriented forces in Ukraine. Secondly, the EU's emphasis on exclusion rather than inclusion in key areas such as visa freedom strongly impacted on public opinion in Ukraine. As a result, the number of Ukrainians identifying with the European project has been declining in recent years (White et. al., 2010). In other words, the constraints of EU policy added to the sclerosis of the Orange leadership top-down and bottom-up.

Both the geopolitical and the value empire paradigms have characterised discourses and foreign policy making in countries with more or less stable authoritarian systems. However, their implications for EU policy are different. Governments following the geopolitical pattern (Azerbaijan, Armenia, Ukraine until 2004 and again since 2010, Belarus between 2008 and 2010) have an interest in cooperation with the EU, primarily in the areas of economy and trade. Although their commitment to the transformative agenda of the EU's foreign policy remains minimal, they are forced to pay lip service to it and allow for certain changes which can favour bottom-up democratic developments (Sasse, 2008). The value empire narrative results in isolationist tendencies in relations with the EU. These were particularly strong in the case of Belarus until 2008, where isolation from the EU was feasible because of close relations with Russia. As for Russia itself, isolation from the EU is not an option given deep energy interdependence between the two. However, isolationist ideas became stronger in the Russian foreign policy debate of the 2000s. During the same period, EU-Russia cooperation on democratisation, the rule of law and human rights has been steadily declining. Internal disagreements on the right policy towards Russia have further undermined the EU's capacities to stand up for its values vis-à-vis Moscow. Today, the EU's scope to influence domestic developments in Russia is minimal. The differences between the geopolitical and the value empire 
paradigm are also reflected in public opinion. While in the case of the former attitudes towards the EU and its engagement are generally friendly, the latter arouses negative feelings about the EU in the respective societies (ENPI 2010, WCIOM 2010).

EU policy in the past decade neither lent sufficient support to reform-oriented political elites open to democracy and integration, nor could it break through the resistance of governments espousing the geopolitical or value empire paradigms. Regardless of its increasing economic weight and political profile, the Union was not able to shape discourses in the region in a way that could have underpinned joint reform efforts and could have helped create the 'ring of well-governed states' envisaged in the European Security Strategy. A lack of internal unity and coherence undermined the EU's ability to take strong positions. This concerns both relations with Russia and the Eastern Partnership countries. Disagreements among Member States also hamper the EU's possibility to offer incentives attractive enough to win over political elites in partner countries. Last but not least, the EU's attitude towards issues such as visa freedom generates feelings of exclusion among the societies of the Eastern European 'outsiders' and diminishes their identification with the European project.

In other words, with the exception of Ukraine and Georgia, where complex learning has taken place to a limited extent, leaderships and political elites in the EU's eastern neighbours have not gone beyond simple learning and partial adjustment of their policies to the demands and expectations of the EU. Some of them have even opted for the full rejection of the EU's socialisation efforts, mainly to protect and preserve power. The EU, on the other hand, could not offer sufficient incentives to persuade at least parts of these elites to open up to the EU's norms and values and allow for the transformation of their respective polities and societies. In a nutshell, contrary to the fears of its most ardent opponents in the post-Soviet space, the EU has not become a value empire.

\section{References}

Alieva, L. (2011). Azerbaijan and Eastern Partnership: partnership through empowerment. Retrieved May 2011, from www.easternpartnership.org

Averre, D. (2009). Competing Rationalities: Russia, the EU and the 'Shared Neighbourhood'. Europe Asia Studies, 61(10), 1689-1714. http://dx.doi.org/10.1080/09668130903278918

Bordachev, T. (2003). V obyatiyakh civilian power. Proet Contra, 8(1), 47-62.

Bosse, G. (2009). Challenges for EU governance through Neighbourhood Policy and Eastern Partnership: the values/security nexus in EU-Belarus relations. Contemporary Politics, 15(2), 215-227. http://dx.doi.org/10.1080/13569770902858152

Centre for European Policy Studies. (2010). European Neighbourhood Watch, 63, 1-2.

Chubais, A. (2003). Liberal'naya imperiya (Liberal empire). Retrieved May 2011, from www.chubais.ru

Commission of the European Union. (2008). Commission Staff Working Document accompanying the Communication from the Commission to the European Parliament and the Council. Eastern Partnership. 823 final.

Council of the European Council. (2003). A Secure Europe for a Better World: European Security Strategy. Brussels: EU Council.

De Waal, T. (2010). The Caucasus. An Introduction. Oxford: University Press.

Delcour, L. (2008). A Missing Eastern Dimension? The ENP and Region-Building in the Post-Soviet Area. In L. Delcour \& E. Tulmets (Eds.), Pioneer Europe? Testing the EU Foreign Policy in the Neighbourhood. (pp. 161- 176). Baden-Baden: Nomos.

Delcour, L. (2011). Shaping the Post-Soviet Space?. EU Policies and Approaches to Region Building. Ashgate.

Dura, G. (2010). EUBAM Moldova-Ukraine. In G. Grevi, D. Helly, \& D. Keohane (Eds.), European Security and Defence Policy: the First Ten Years (1999-2009) (pp. 275-286). Paris: EUISS.

ENPI Info Centre Series. (2010). Perceptions of the EU in Neighbourhood Partner Countries. Retrieved May, 2011, from www.enpi-info.eu

EU-Neighbourhood East Parliamentary Assembly. (2009). What is Euronest. Retrieved May 2011, from http://www.euronest.europarl.europa.eu

Feichtinger, W. (2010). The Georgian-Abkhaz Conflict. In W. Feichtinger et. al. (Eds.), Failed Prevention The Case of Georgia (pp. 37-58). Vienna: National Defence Academy. 
Fischer, S. (2003). Russlands Westpolitik in der Krise 1992-2000. Eine konstruktivistische Untersuchung. Frankfurt a.M./ New York: Nomos.

Fischer, S. (2007). The EU and Russia. Conflicts and Potentials of a Difficult Partnership. SWP Research Paper 1, January.

Fischer, S. (2009). Executive Summary. In S. Fischer (Ed.), Back from the cold? The EU and Belarus in 2009 (pp. 119). EUISS: Chaillot Paper.

Fischer, S. (2011). The ENP Strategic Review: The EU and its neighbours at a crossroads. EUISS: Analysis, May 2011.

Fischer, S. (2008). Ukraine as a regional actor. In S. Fischer (Ed.), Ukraine: Quo Vadis? (Vol. 108, pp. 119-146). EUISS: Chaillot Paper.

Gänzle, S. (2009). EU Governance and the European Neighbourhood Policy: A Framework for Analysis. Europe Asia Studies, 61(10), 1715-1734. http://dx.doi.org/10.1080/09668130903278926

Goldstein, J., \& Keohane, R. (1993). Ideas and Foreign Policy: An Analytical Framework. In J. Goldstein, \& R. Keohane (Eds.), Ideas and Foreign Policy. Beliefs, Institutions and Political Change. Ithaca and London.

Gromadzki, G. (2009). Belarusian foreign policy - change or continuity?. In S. Fischer (Ed.), Back from the Cold? The EU and Belarus in 2009 (pp. 119). Paris: EUISS Chaillot Paper.

Gross-Stein, J. (1996). Political Learning by Doing: Gorbachev as Uncommitted Thinker and Motivated Learner. In R. N. Lebow, \& T. Risse-Kappen (Eds.), International Relations Theory and the End of the Cold War. New York.

Gryshenko, K. (2010). Speech at the Swedish Institute of International Affairs. Retrieved May, 2011, from www.mfa.gov.ua

Haukkala, H. (2009). From Zero-Sum to Win-Win? The Russian Challenge to the EU's Eastern Neighbourhood Policies. European Policy Analysis (pp. 12).

Hudson, V. M. (1997), Culture and Foreign Policy: Developing a Research Agenda. In V. M. Hudson (Ed.), Culture and Foreign Policy. Boulder.

Huff, A. (2011). The role of EU defence policy in the Eastern neighbourhood (pp. 91). EUISS: Occasional, May 2011.

International Crisis Group. (2010). Azerbaijan: Vulnerable Stability (pp. 207). ICG Report.

International Crisis Group. (2011). Armenia and Azerbaijan: Preventing War (pp. 60). ICG Policy Briefing. Europe Briefing.

Kratochwil, P. (2008). The Discursive Resistance to EU-Enticement: The Russian Elite and (the Lack of) Europeanisation. Europe-Asia Studies, 60(3), 397-422. http://dx.doi.org/10.1080/09668130801947994

Lapid, Y., \& Kratochwil, F. (1996). The Return of Culture and Identity in IR Theory. Boulder and London.

Lavrov, S. (2009). Conversation with Russia. Transcript from the 2009 Brussels Forum. Retrieved May 2011, from http://brussels.gmfus.org

Leshchenko, N. (2008). The National Ideology and the Basis of the Lukashenka Regime in Belarus. Europe-Asia Studies, 60(8), 1419-1433. http://dx.doi.org/10.1080/09668130802292234

Manners, I. (2002). Normative Power Europe: A Contradiction in Terms. Journal of Common Market Studies, 40, 235-258. http://dx.doi.org/10.1111/1468-5965.00353

Marchetti, A. (2008). Consolidation in Times of Crisis? The Setup of the European Neighbourhood Policy and its Challenges. In L. Delcour, \& E. Tulmets (Eds.), Pioneer Europe? Testing the EU Foreign Policy in the Neighbourhood (pp. 21- 34). Baden-Baden: Nomos.

Milliken, J. (1999). The Study of Discourse in International Relations: A Critique of Research and Methods. European Journal of International Relations, 5(2), 225-254. http://dx.doi.org/10.1177/13540661990050020 03

Ministry of Foreign Affairs, Russia. (1999). Medium-term Strategy forDevelopment of Relations between the Russian Federation and the European Union (2000-2010). Retrieved May 2011, from www.mid.ru

Noutcheva, G. et al. (2004). Europeanization and Secessionist Conflicts: Concepts and Theories. Journal of Politics and Minority Issues in Europe, 5(1). 
Pelzynska-Nalecz, K. (2011). Integration or Imitation? EU policy towards its Eastern Neighbours. PSW Studies, 36. Warsaw: OSW.

Popescu, N., \& Wison, A. (2009). The Limits of Enlargement-Lite: European and Russian Power in the Troubled Neighbourhood. European Council on Foreign Relations: Policy Report.

Popescu, N. (2011). EU Foreign Policy and Post-Soviet Conflicts. Stealth intervention. London and New York: Routledge.

Prozorov, S. (2007). The narratives of exclusion and self-exclusion in the Russian conflict discourse on EU-Russia Relations. Political Geography, 26(3), 309-329. http://dx.doi.org/10.1016/j.polgeo.2006.10.015

Report on the Implementation of the European Security Strategy: Providing Security in a Changing World. Brussels: S407/08 (December 11, 2008).

Saakashvili, M. (2008). Inaugural speech (21 January 2008). Retrieved May 2011, from www.civil.ge

Sasse, G. (2008). The European Neighbourhood Policy: Conditionality Revisited for the EU's Eastern Neighbours. Europe-Asia Studies, 60(2), 295-316. http://dx.doi.org/10.1080/09668130701820150

The Council of the European Union. (2008). Council Joint Action 2008/760/CFSP of 25 September 2008 appointing the European Union Special Representative for the crisis in Georgia. Official Journal of the European Union. L 259/16 (September 27, 2008).

Triantaphyllou, D., \& Tsantoulis, Y. (2008). Looking Beyond the Georgian Crisis: the EU in Search of an Enhanced Role in the Black Sea Region (no. 8). ICBSS Policy Brief, Athens.

WCIOM. (2010). Rossiya I Evropa: Sotrudnichestvo ili protivostoyanie?. Moskva: WCIOM.

Weldes, J. (1996). Constructing National Interests. European Journal of International Relations, 2(3), 275-318. http://dx.doi.org/10.1177/1354066196002003001

Wendt, A. (1999). Social Theory of International Politics. Cambridge University Press. http://dx.doi.org/10.1017/CBO9780511612183

White, S., Korestela, J., \& McAllister, I. (2008). A Wider Europe? The View rom Russia, Belarus and Ukraine. Journal of Common Market Studies, 46(2), 219-241. http://dx.doi.org/10.1111/j.1468-5965.2007.00775.x

White, S., McAllister, I., \& Feklyunina, V. (2010). Belarus, Ukraine and Russia: East or West? The British Journal of Politics and International Relations, 12, 344-367. http://dx.doi.org/10.1111/j.1467-856X.2010.00410.x

Wolczuk, K. (2008). Ukraine and its relations with the EU in the context of the European Neighbourhood Policy. In S. Fischer (Ed.), Ukraine: Quo Vadis? (108, pp. 87-118). EUISS: Chaillot Paper.

Wolowski, P. (2008). Ukrainian politics after the Orange Revolution. How far from democratic consolidation? In S. Fischer (Ed.), Ukraine: Quo Vadis? (108, pp. 25-54). EUISS: Chaillot Paper.

Yanukovich, V. (2011). Address of the President of Ukraine to Verkhovna Rada: Development of Ukraine stands for modernisation and innovation. Retrieved May 2011, from www.president.gov.ua

Yushchenko, V. (2005). Inaugural address of the President of Ukraine Victor Yushchenko to the Ukrainian people on Independence Square. Retrieved May 2011, from www.kmu.gov.ua

\section{Notes}

Note 1. There is no agreement among experts and policy makers in the EU, the US, Russia and the other post-Soviet countries on how to call the region. In the Russian discourse it is usually denominated as either the 'near abroad' (blizhee zarubezhee) or the post-Soviet space (post-sovetskoe prostranstvo) which reflects the Russian believe in a historical, cultural and political proximity with its immediate neighbours. EU language has developed along the lines of EU policies: with the unfolding of different policy instruments for relations with Russia, on the one hand, and Belarus, Ukraine, Moldova and the three South Caucasian Republics, on the other, a linguistic separation took place between Russia and what the EU today calls its 'Eastern neighbourhood'. The notion of Eurasia, which is often used in the American discourse, has a specific (right wing conservative) political meaning in the Russian debate and has not become rooted in the European context because of the geopolitical tradition associated with it. The mutual resentment with regard to the respective labelling reflects the political tensions between Russia and the EU over the region. In order not to fall into the trap of the unconscious use of politically loaded expressions the region will be alternately called either post-Soviet space or Eastern neighbourhood. 
Note 2. Russia: 1997, Ukraine and Moldova: 1998, Georgia, Armenia, Azerbaijan: 2000. The ratification of a PCA with Belarus was stopped by the EU in 1997 in protest against the authoritarian development of that country (Fischer 2009).

Note 3. Common Economic Spaces; Common Space of Freedom, Security and Justice; Common Space of External Security; Common Space of Research and Education,. Despite its rejection of political participation in the ENP, Russia remains eligible for the ENPI. However, technical assistance and other aid to Russia have rapidly declined in the past 10 years.

Note 4. GUAM and the Community of Democratic Choice provide examples for regional organisations in the post-Soviet space which have been founded for this purpose (Fischer 2008: pp 126-128).

Note 5. The Russian Federation Medium Term Strategy towards the European Union (2000-2010), published in autumn 1999, for the first time explicitly ruled our Russian EU membership (Fischer 2007). 